\title{
Utilization of Associated Oil Gas: Geo-ecological Problems and Modernization of the State
}

\author{
L. Z. Zhang ${ }^{1,2}$ and H. Y. Sun ${ }^{1,3(\bowtie)}$ \\ ${ }^{1}$ Department of Mineral Developing and Oil \& Gas Engineering, \\ RUDN University, Moscow, Russia \\ 657273629@qq.com \\ ${ }^{2}$ Liaoning Shihua University, Fushun, China \\ ${ }^{3}$ Qinhuangdao Experimental Middle School, Qinhuangdao, China
}

\begin{abstract}
In the world vast of oil is extracted, especially in China. Respectively produce associated petroleum gas is in a large volume. There are geoecological problems in the utilization of associated petroleum gas. In connection with the increasing requirements for the preservation of the state of the biosphere in China, the process of modernization was begun. Chinese modernization of associated petroleum gas utilization is presented.
\end{abstract}

Keywords: Associated petroleum gas $\cdot$ Modernization $\cdot$ Technology Geo-ecological problems

\section{Introduction}

Associated petroleum gas (after this APG) is a mixture of various gaseous hydrocarbons dissolved in oil and released in the process of extraction and preparation of oil. The oil gases also include gases released in the operations of thermal processing of oil (cracking, reforming, hydrotreating, etc.), consisting of saturated and unsaturated (methane, ethylene) hydrocarbons.

From geology, APG is often formed during the Ordovician and Silurian periods. Sometimes it is built late to the Cretaceous. (Vorobiev and Zhang 2018).

\section{Methods and Approaches}

The PRC's world ranking in oil production is quite high and, accordingly, the volumes of simultaneously produced associated gas are very significant. In 2011-2013 in China, APG was provided in the amount of $27.3,28.9,30.2$ billion $\mathrm{m}^{3}$. In addition, the share of production took more than $5.1 \%$ in the world.

Previously, in China, APG was traditionally considered not as a valuable resource, but as a by-product of oil production, the simplest method of which utilization is flaring in many fields, especially in Northeast China. 


\section{Results and Discussion}

Associated gas recovery technology using membrane separation is based on the following steps:

- removing micro solid particles, crude oil and heavy hydrocarbon emulsion contained in associated gas;

- after preliminary impurity removal, heating up to $590{ }^{\circ} \mathrm{C}$ in a heat exchanger;

- introducing into a liquid rotary compressor;

- introducing the heated gas into a desulfurization tank, and desulfurizing;

- introducing the desulfurized gas into a membrane separator, and separating;

- introducing the gas from the membrane separator to a molecular sieve tank, and performing deep desulfurization and decarburization;

- cooling to obtain the product (Mo 2013).

This technological process is quite simple and convenient in industrial operation, and besides, it is characterized by low operating costs, high recovery rate and can be, after a little adaptation, widely circulated.

\section{Conclusions}

Associated petroleum gas will become a valuable raw material for further processing. China's economy needs to use APG to reduce greenhouse gas emissions.

Modernization of processing of APG in China and its prospects lie in the area of increasing the efficiency of processing of associated gas, reducing energy consumption in the course of processing, flexible operation, convenient installation and operation.

\section{References}

Mo JL (2013) Recovery process for petroleum associated gas. China Patent CN102994180A, 27 March 2013

Vorobiev AE, Zhang LZ (2018) Apply innovative technologies for processing of associated gas in China. Eurasian Sci. J. 10(2)

Open Access This chapter is licensed under the terms of the Creative Commons Attribution 4.0 International License (http://creativecommons.org/licenses/by/4.0/), which permits use, sharing, adaptation, distribution and reproduction in any medium or format, as long as you give appropriate credit to the original author(s) and the source, provide a link to the Creative Commons license and indicate if changes were made.

The images or other third party material in this chapter are included in the chapter's Creative Commons license, unless indicated otherwise in a credit line to the material. If material is not included in the chapter's Creative Commons license and your intended use is not permitted by statutory regulation or exceeds the permitted use, you will need to obtain permission directly from the copyright holder.

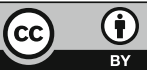

